\title{
Antibacterial Activity of Extract Ethyl Acetate and Ethanol of Raru (Vatica pauciflora Blume)
}

\author{
Ida Duma Riris ${ }^{1}$, Endang Sulistyarini Gultom ${ }^{2}$, Lazuardi $^{3}$, Albinus Silalahi $^{4}$, Dewi Purba ${ }^{5}$, \\ Andriani Syafitry 6 \\ \{dumariris@gmail.com\} \\ Faculty of Mathematics and Natural Science, State University of Medan, \\ North Sumatera, Indonesia ${ }^{1,2,3,4,5,6}$
}

\begin{abstract}
This research purpose is to show the inhibition of the extract of ethanol and ethyl acetate stem bark and leaf of Raru according to the causes of bacterial E-coli (ATCC 25922) and St Aureus (ATCC 25923) with variation concentration $10 \%, 5 \%, 2.5 \%$ and $1.25 \%$. Methods used were diffusion with disk blank paper and disk cloramphenicol as a control. The highest result observed on $10 \%$ concentration among the variation. This concentration then compared with control and the result as follow for stem bark of ethanol and ethyl acetate exctract for bacterial E-coli and St Aureus : 14.7 and $14.5 ; 11.6$ and 13.5. for leaf : 14.6 and $13.5 ; 14.0$ and 13.30
\end{abstract}

Keywords: Raru (Vatica pauciflora Blume) ; Anti Bacteria E-coli and St Aureus

\section{Introduction}

The Raru plants belongs to the family Dipterocarpaceae for a long time known as medicinal plant by the community Tapanuli. was used as an additional drink nira aren. The purpose of adding flavour is known as a traditional drink called Tuak (Gunawan, 2011). Once of them has been investigated In North Sumatera, Central Tapanuli, there are Raru plants types (vatica pauciflora Blume) which on phytochemical was founded flavonoid compound in activity as anti-diabetic in in vitro (Riris, 2014). Many of this plant was used as a herbal by people in the world (Al - Rubiay et al, 2008).

The bacteria have been known to cause infections. The utilization of plants are often used in traditional medicine as a preventive of infections (Vauren s. f. van, 2008). Activity antibacterial test can be done to find out if there are activities of the plant is antibacterial and the most widely method used performe by the method of diffusion discs (Natheer et al, 2012). Methods of diffusion affected many of the physical and chemical factors other than simple interactions between drugs and organism (e.g., the nature of the medium and the ability of molecular size, diffusion, and drug stability) (Jawetz et al., 2007). On researches to analyze the inhibition of plant extracts commonly used type of Gram positive bacteria and Gram negative (Palombo Enzo A, et al, 2001). On this research aim to see if extracts of leaves and bark gives the barriers against bacteria: Staphylococcus Aereus and Escherchichia Coli, with measurement results drag zone $(\mathrm{mm}) \leq 10$ classified is not active; 11-15 (weak); 16-20 (medium); and $\geq 20$ (strong) (Greenwood, 1995). 


\section{Material And Method}

\subsection{Plant Samples}

The raru (Vatica Pauciflora Blume) were collected from the Central Tapanuli of North Sumatra. Chemicals used: extract of stem bark ethyl acetate and ethanol, MHA (Mueller Hinton Agar Oxoid CM0337), physiological $\mathrm{NaCl}$ 0.9\%, Mc Farland, 0.5.\%, paper discs, chloramphenicol, DMSO, ethanol, cotton, tissue, heat-resistant plastic.

\subsection{Preparation of The Sample}

$3 \mathrm{~kg}$ samples were washed, air-dried and then sift to be powder bark and leaf raru (vatica pauciflora Blume).

\subsection{Extraction}

Extraction was prepared with maceration in ethanol and ethyl acetate for 3 x 24 hours. On the process of maceration was performed 3 times then repetition was filtered by using a Buchner so obtained the filtrate and residue. The filtrate is obtained with a vacuum rotary evaporator according the boiling point of the solvent used i.e. ethanol solvents with boiling point of $78.4^{\circ} \mathrm{C}$, and ethyl acetate with a boiling point of 77,10 so obtained extracts.

\subsection{Antibacterial Screening}

\subsubsection{Sterilization Equipment}

Glass tools sterilized using the oven at a temperature of $180{ }^{\circ} \mathrm{C}$ during 2 hours, as for metal tools and tools which no heat resistant and medium on heating with high temperature, sterilized in an autoclave and wrapped with aluminum foil at $121{ }^{\circ} \mathrm{C}$ and 2 atm for 15 minutes.

\subsubsection{The Creation of Media so that (Satish, 2008)}

Media in order for the MHA (Mueller Hinton Agar) is a common medium media was used to grow the bacteria Escherichia coli and stphylococcus aureus. Weighing as much as 38 $\mathrm{g}$ of MHA media (Oxoid CM0337) then add $1 \mathrm{~L}$ aquadest ,mixed and sterilized in autoclave at $121{ }^{\circ} \mathrm{C}$ for 15 minutes, then put the media into the BSC (Bio Safety Cabinet) then the media pour into petri dish and keep in an incubator for 24 hours at $37^{\circ} \mathrm{C}$

\subsubsection{Cultured of Bacterial Suspension (sukandar et al., 2010)}

The bacteria will be used first bred prior to use for testing. By using a cotton bud taken bacteria and inserted into the impulse tube, after it suspended bacteria into the $\mathrm{NaCl}$ $0.9 \%$ as much as $2 \mathrm{~mL}$ afterwards in the vortex and levels compared with a $0.5 \mathrm{McFarland}$ Standard ( $0.05 \mathrm{~mL}$ Barium Chloride in $9.95 \mathrm{~mL}$ of Acid Sufat, $10-8 \times 1.5 \mathrm{~mL}$ ) (Whitman and MacNair, 2010). 


\subsection{Methods of Paper Disc Diffusion}

Weight $100 \mathrm{mg} / \mathrm{mL}$ extracted test with concentration of $10 ; 5 ; 2.5$ dan $1.25 \mathrm{mg} / \mathrm{mL}$ is made by doing serial dilution with $1 \mathrm{~mL}$ of DMSO extract (Natheeret al., 2012). Paper discs were sterilized with $20 \mu \mathrm{L}$ aqueous extract dried in sterile petri at room temperature. A suspension of bacteria taken with a cotton bud and smeared in the media of MHA (Oxoid CM0337) which prepared in advance. The positive control used is cloramphenikol antibiotic discs while the negative control used is solvent DMSO (Natheer et al., 2012).

\section{Results And Discussion}

Table 1. Diameter zone of inhibition $(\mathrm{mm})$ of ethanol and ethyl acetate Extract of stem bark of to bacteria Escherichia coli

\begin{tabular}{l|lllll}
\hline $\begin{array}{l}\text { Extractstem bark of } \\
\text { raru }\end{array}$ & $\begin{array}{l}\text { Concentration } \\
(\%)\end{array}$ & D1 & D2 & D3 & D \\
\hline \multirow{5}{*}{ Ethyl acetat } & 0 & 0 & 0 & 0 & 0 \\
& 10 & 13.2 & 13 & 13.3 & 13.3 \\
& 5 & 9.6 & 9.9 & 9.5 & 9.9 \\
& 2.5 & 8.5 & 8 & 8 & 8.5 \\
Chloramphenocol & 1.25 & 7 & 7 & 7 & 7 \\
& 0,02 & 18,8 & 18.6 & 18.5 & 18.8 \\
& 0 & 0 & 0 & 0 & 0 \\
& 10 & 13 & 13 & 13.5 & 13.5 \\
Chloramphenicol & 5 & 11 & 12 & 12.45 & 12.5 \\
& 2.5 & 8.4 & 9 & 10 & 10 \\
& 1.25 & 6 & 6.5 & 6 & 6.5 \\
& 0.02 & 18.8 & 18.6 & 18.4 & 18.8 \\
\hline
\end{tabular}


Table 2. Diameter zone of inhibition ( $\mathrm{mm}$ ) of ethanol and ethyl acetate Extract of stem bark of to bacteria Staphylococcus aureus

\begin{tabular}{|c|c|c|c|c|c|}
\hline \multirow{2}{*}{$\begin{array}{l}\text { Extract stem } \\
\text { bark of raru }\end{array}$} & \multirow{2}{*}{$\begin{array}{c}\text { Concent } \\
\text { ration } \\
(90)\end{array}$} & \multicolumn{4}{|c|}{$\begin{array}{c}\text { Diameter zone of } \\
\text { inhrihition (mm) } \\
\text { St. aureus }\end{array}$} \\
\hline & & $\mathrm{D}_{\mathrm{i}}$ & $\mathrm{D}_{2}$ & $\mathrm{D}_{3}$ & $\mathrm{D}$ \\
\hline \multirow{5}{*}{ Ethyl acetate } & 0 & 0 & 0 & 0 & 0 \\
\hline & 10 & 14 & 13.5 & 13 & 14 \\
\hline & 5 & 10 & 10.5 & 10 & 10.5 \\
\hline & 2.5 & 9 & 9 & 8.5 & 9 \\
\hline & 1,25 & 6 & 6 & 6 & 6 \\
\hline Chloramphenizol & 0,02 & 17,8 & 18 & 18,5 & 18,5 \\
\hline \multirow{5}{*}{ Ethanol } & 0 & 0 & 0 & 0 & 0 \\
\hline & 10 & 14.5 & 14 & 14.6 & 14.6 \\
\hline & 5 & 12.5 & 12.4 & 12.4 & 12.5 \\
\hline & 2.5 & 10.8 & 10.5 & 10 & 10.8 \\
\hline & 1.25 & 8 & 8.7 & 8.5 & 8.7 \\
\hline Chloramphenicol & 0,02 & 20 & 20,3 & 20,1 & 20,3 \\
\hline
\end{tabular}

Table 3. Diameter zone of inhibition ( $\mathrm{mm}$ ) of raru leaf ethanol and ethyl acetate extract to bacteria Escherichia coli

\begin{tabular}{|l|c|c|c|c|c|}
\hline \multirow{3}{*}{$\begin{array}{c}\text { Raru leaf } \\
\text { extract }\end{array}$} & \multirow{2}{*}{$\begin{array}{c}\text { Concent } \\
\text { ration } \\
(\%)\end{array}$} & \multicolumn{4}{|c|}{$\begin{array}{c}\text { Diameter zone of } \\
\text { inhibition }\end{array}$} \\
\cline { 3 - 7 } & & D1 & D2 & D3 & D \\
\hline \multirow{4}{*}{ Ethyl acetate } & 10 & 11,1 & 11,6 & 11,6 & 11,6 \\
& 5 & 9,5 & 9,6 & 9,5 & 9,6 \\
\hline Chloramphenicol & 2,5 & 9,3 & 9 & 9 & 9,3 \\
\hline & 1,25 & 6,5 & 6 & 6 & 6,5 \\
\hline Ethanol & 10 & 14,7 & 14,6 & 14 & 14,7 \\
& 5 & 11,2 & 11 & 10 & 11,2 \\
& 2,5 & 9 & 8,7 & 8,5 & 9 \\
\hline Chloramphenicol & 1,25 & 6,1 & 6,1 & 6,2 & 6,2 \\
\hline
\end{tabular}




\begin{tabular}{|l|c|c|c|c|c|}
\hline \multirow{2}{*}{$\begin{array}{c}\text { Raru leaf of } \\
\text { extract }\end{array}$} & $\begin{array}{c}\text { Concent } \\
\text { ration } \\
(\%)\end{array}$ & \multicolumn{4}{|c|}{$\begin{array}{c}\text { Diameter zone of } \\
\text { inhibition (mm) }\end{array}$} \\
\cline { 3 - 7 } & 10 & 12,5 & 13 & 13,5 & 13,5 \\
\hline \multirow{2}{*}{ Ethyl acetate } & 5 & 10,3 & 12 & 12,2 & 12,2 \\
& 2,5 & 9 & 9,3 & 9,5 & 9,5 \\
& 1,25 & 7,5 & 7 & 7,6 & 7,6 \\
\hline chloramphenicol & 20,3 & 20,3 & & & \\
\hline & 10 & 14 & 14,5 & 14 & 14,5 \\
& 5 & 11 & 10,8 & 11,5 & 11,5 \\
Ethanol & 2,5 & 8 & 9 & 8,8 & 9 \\
& 1,25 & 8 & 7,5 & 7 & 8 \\
\hline chloramphenicol & 23,2 & & & & \\
\hline
\end{tabular}

Tabel 4. Diameter zone of inhibition $(\mathrm{mm})$ of raru leaf ethanol and ethyl acetate extract to bacteria Stahylococcus aureus.

Following are the results of the image zone the resistance of each extract and test bacteria.

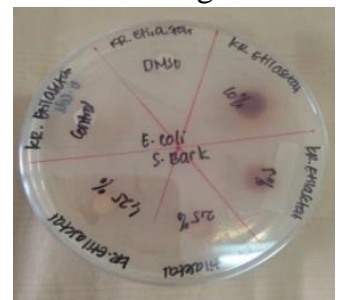

A

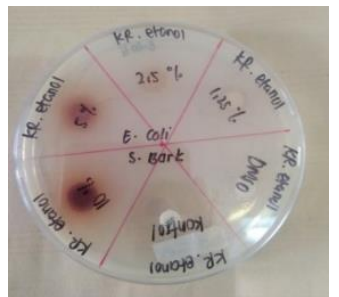

B

Figure 1. (A) Zone inhibition extract EA and (B) ET leaf to E.coli

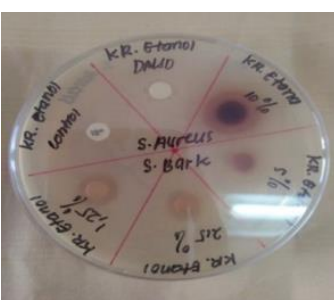

A

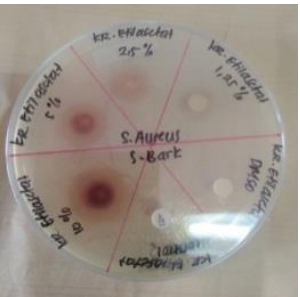

B

Figure 2. (A) Zone inhibition extract ET and (B) EA to E.coli Staphylococcus aureus
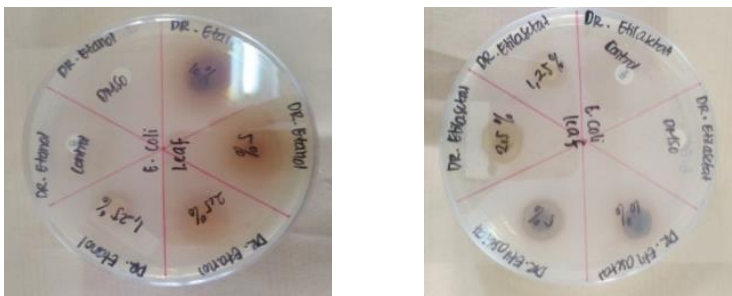
A

B

Figure 3. (A) Zone inhibition extract EA and (B) ET leaf to E.coli E. coli

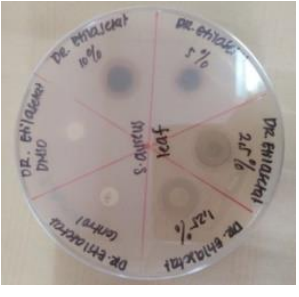

A

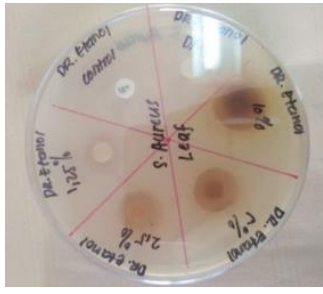

B

Figure 4. (A) Zone inhibition extract EA and (B) ET leaf to Staphylococcus aureus.

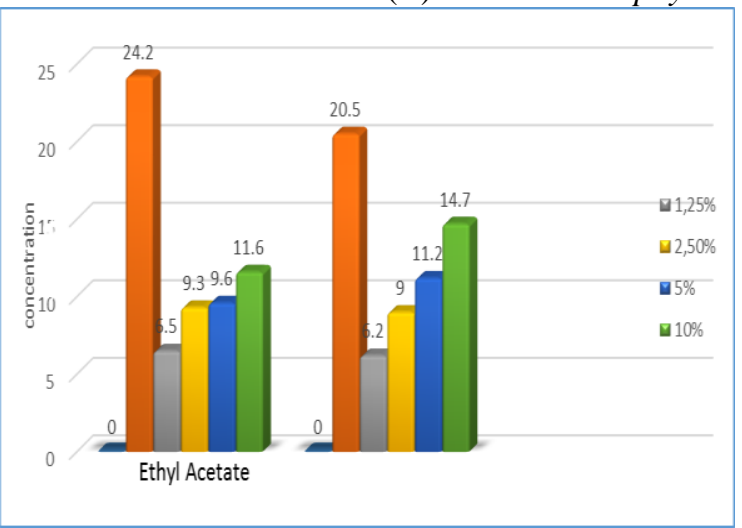

Figure 5. Zone inhibition antibacterial extract of raru stem bark against E.coli

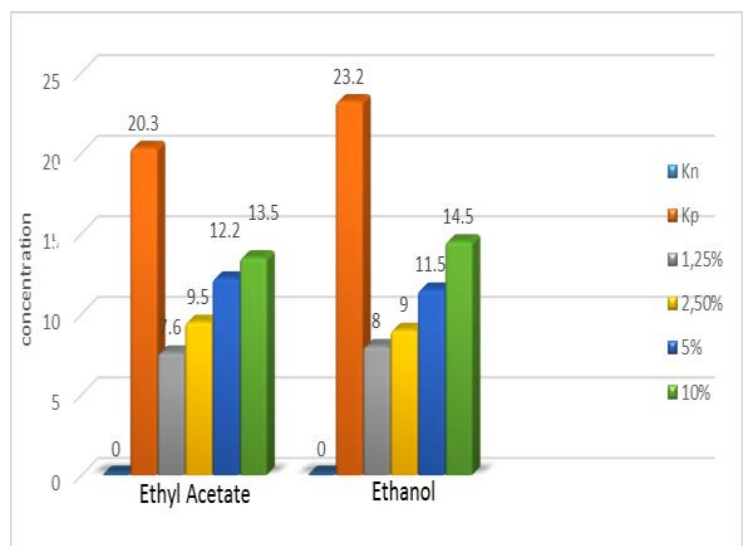


Figure 6. Zone inhibition antibacterial extract of raru stem bark against staphylococcus aureus

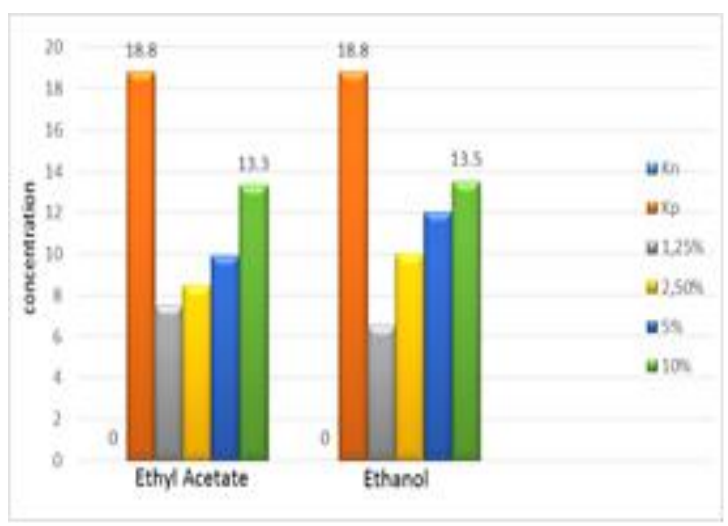

Figure 7. Zone inhibition antibacterial extract of raru leaf against Escherichia coli.

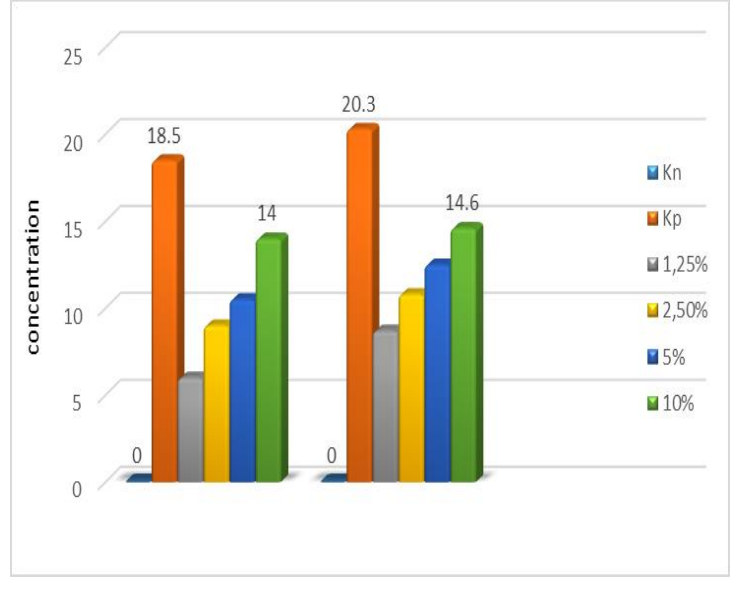

Figure 8. Zone inhibition antibacterial extract of raru leaf against Staphylococcus aureus.

It shown inhibition zone widest at concentrations of $10 \%$ ethanol extract of the leaves and bark. Antibacterial activity of ethyl acetate extract of raru stem bark on staphylococcus aureus bacteria has a larger diameter compared to Escherichia coli bacteria. While the ethanol extract of raru stem bark on Escherichia coli bacteria has a clear zone diameter greater than that of staphylococcus aureus. From the results obtained in the extract, it can be seen that the higher the concentration, the clearer zones produced are also wider, the bark and leaf extracts have strong antibacterial activity (Greenwood, 1995).

The activity test of ethanol and ethyl acetate extracts from the bark and leaves of Raru (Vatica pauciflora Blume) inhibited E. coli as gram negative bacteria and St Aureus gram positive bacteria, a greater variation in concentration gave a barrier to wider bacteria. 
Acknowledgments. To the Medan State University research institute, and funding providers of the Directorate of Research and Community Service with the contract number: 027 / UN 33.8 / LL / 2018

\section{References}

[1] Al Rubiay , K.K., Jaber N.N, B.H Al Mhaawe., Alrubay K.,. Antimicrobial Efficasy of Henna Extracts, Oman Medicinal Journal.( 2008)

[2] Greenwood, D.,. Preserving the miracle of antibioticsThe Lancet, 345(8961), 1371. doi:10.1016/s0140-6736(95)92572-4(1995)

[3] Jawetz, Melnick dan Adelbergs. ,. Mikrobiologi Kedokteran Edisi 23. Salemba Medika, jakarta.( 2007)

[4] Natheer, S.E., C. Sekar., P. Amutharaj., M. Syed Abdul Rahman and K. KerozKhan,. Evaluation of Antibacterial Activity of Morinda citrifolia,Vitex trifolia and Chromolaena odorata. African journal of Pharmacy andPharmacologyVol. 6 (11): 783-788.( 2012)

[5] Palombo Enzo, A., Semples Susan, J, x. Antibacterial activity of traditional Australian medicinal plant., journal of Ethnopharmacology vol (77):151-157. http://doi.org/10.1016/S0378-8741(01)00290-2(2012)

[6] Pasaribu G dan Setyawati T.,. Aktivitas Antioksidan dan Toksisitas Ekstrak Kulit Kayu Raru (Cotylelobium Sp), Pusat Litbang Keteknikan Kehutanan dan Pengolahan Hasil Hutan.( 2011)

[7] Pelczar, MJ,. Dasar-dasar Mikrobiologi. Jakarta: UI Press.( 2005)

[8] Riris I.D, Barus T, Simanjuntak P and Wirjosentono B,. Isolation and Structure Elucidation of Bioactive Compounds Chemical as Inhibitor of The Enzime $\alpha$ - Glucosidase Raru Bark Ethanol Extract (Vatica Pauciflora Blume), International Journal Of Chemistry 6(2), doi.org/105539/IJC.( 2014)

[9] Satish, S., M.P.,Raghavendra and K. A, Raveesha,. Evaluation of antibacterial potential of some plants agent human pathogenic bacteria, Advances in Biological Research10(2): 44-48. (2008)

[10] Sukandar, D., Radiastuti, N., jayanegara, I., Hudaya, A.,. karakterisasi senyawa aktif antibakteri ekstrak air bunga kecombrang (Etlingera elatior) sebagai bahan pangan fungsional, valensi 2(1):333-339.( 2010)

[11] Vauren Van, S.F., , Antimicrobial activity of South African medicinal plants., journal of Ethnopharmacology. Vol 119 (3): 462-472. https://doi.org/10.1016/j.jep.2008.05.038.( 2008) 